\title{
EVALUASI MENGENAI KUANTITAS DAN KUALITAS RUANG TERBUKA HIJAU DI WILAYAH DKI JAKARTA
}

\author{
Rizka Novianty, Henita Rahmayanti, Amos Neolaka
}

\begin{abstract}
Abstrak
Penelitian ini bertujuan untuk mengevaluasi ruang terbuka hijau (RTH) di wilayah DKI Jakarta, evaluasi yang dilakukan adalah dari segi kuantitas dan kualitas. Kuantitas yaitu jumlah ruang terbuka hijau (RTH) dan kualitas yaitu sejauh mana pemanfaatan dan kondisi ruang terbuka hijau (RTH) di wilayah DKI Jakarta.

Penelitian ini dilakukan di seluruh wilayah Kotamadya di DKI Jakarta pada bulan Februari hingga Juni 2011. Pada penilitian ini digunakan populasi berupa seluruh wilayah DKI Jakarta dan sample berupa beberapa wilayah ruang terbuka hijau yang ada di setiap wilayah Kotamadya di DKI Jakarta tergantung dengan bentuk yang dikembangkan di setiap wilayah administratif. Pada penelitian ini akan mengkaji kesesuaian data yang ada pada Dinas Tata Ruang DKI dengan kebenaran data langsung di lapangan.. Pada penelitian ini juga akan dikaji seberapa besar pemanfaatan ruang terbuka hijau dan bagaimana kondisi ruang terbuka hijau (RTH) di wilayah DKI Jakarta.

Dari penelitian, pendataan dan survey langsung di lapangan didapat jumlah ruang terbuka hijau (RTH) di wilayah DKI Jakarta sebesar 9,12\%. Jumlah tersebut masih jauh dari target Pemda DKI Jakarta itu sendiri yakni 13,84\%. Dari pengamatan secara kualitas, didapatkan pemanfaatan dan kondisi yang berbeda- beda dari setiap RTH di setiap wilayah. Bentuk RTH yang dikembangkan di setiap wilayah adminstratif di DKI Jakarta juga berbeda- beda tergantung dengan tujuan pemanfaatannya. Beberapa RTH yang disurvei terlihat dalam kondisi memprihatinkan terutama pada RTH pemukiman dan kondisi yang cukup baik terlihat pada Taman, baik taman bangunan umum, taman interaksi, maupun taman rekreasi.
\end{abstract}

Kata kunci : Ruang Terbuka Hijau

\begin{tabular}{|l|c|r|}
\hline Rizka Novianty & Dra. Henita Rahmayanti, M.Si & Prof. Dr. Amos Neolaka, M.Pd \\
Alumni Jurusan Teknik Sipil & Staff Pengajar Jurusan Teknik Sipil & Staff Pengajar Jurusan Teknik Sipil \\
Fakultas Teknik & Fakultas Teknik & Fakultas Teknik \\
Universitas Negeri Jakarta, & Universitas Negeri Jakarta, 13220 & Universitas Negeri Jakarta, \\
13220 & email : henita.rahmayanti@yahoo.com & 13220 \\
\hline
\end{tabular}




\section{PENDAHULUAN}

Daerah khusus lbukota (DKI) Jakarta, seperti halnya kota-kota besar di negara-negara lain, dalam pertumbuhannya memang menghadapi dua fenomena yaitu; (a) menurunnya lingkungan fisik kritis perkotaan, dan (b) masalah sosial seperti urbanisasi, tumbuh berkembangnya permukiman kumuh, lunturnya budaya asli serta gejala sosial lainnya. Pertumbuhan Penduduk DKI Jakarta yang cenderung semakin meningkat seiring dan sejalan dengan tumbuh berkembangnya wilayah perkotaan menyebabkan kebutuhan akan lahan semakin meningkat. Kondisi ini nampaknya memacu terhadap luas kawasan kumuh yang kini tercatat 11.340 ha, atau (17,3\% dari luas daratan DKI Jakarta) pada akhir Januari 2011

Kondisi tersebut pada akhirnya berdampak pada menurunnya daya dukung lingkungan hidup kota Jakarta, yang juga berdampak pada munculnya berbagai bencana yang hampir rutin terjadi. Mencermati fenomena lingkungan fisik kritis perkotaan seperti uraian di ini, munculah kesadaran bagi Pemerintah DKI Jakarta untuk mengendalikan atau setidaknya meminimalisir berbagai kerusakan yang terjadi akibat penurunan daya dukung lingkungan. Langkah awal yang dilakukan, dengan dibentuknya Dinas-dinas Teknis (Pertanian, Pertamanan, dan Kehutanan), yang secara langsung memiliki embanan tugas untuk penanganannya. Pertimbangan itu pula yang cukup mendasar untuk memunculkan kesadaran Pemda DKI, atas dasar peran fungsi dan jasa biologis pepohonan yang telah terbukti dan mampu meminimalisir serta mengendalikan berbagai bentuk cemeran dan sumber-sumber penyebab lainnya. Hal ini mengingat bahwa keberadaan ruang terbuka hijau dapat berfungsi sebagai paru-paru kota dan berbagai fungsi lainnya. Di sisi lain, ruang terbuka hijau perkotaan juga berperan sebagai pemandu keindahan kota, pusat kesegaran jasmani, rekreasi alam dan sumber produksi terbatas. Meperhatikan meningkatnya laju pertambahan jumlah penduduk, dan semakin meningkatnya sumber-sumber penyebab lingkungan fisik kritis perkotaan, serta peran fungsi dan jasa biologis pepohonan, untuk itu niat kesungguhan dalam membangun ruang terbuka hijau, merupakan langkah dan program yang dinilai cukup strategis. Atas dasar itulah Perda DKI Jakarta No. 26 tahun 2007 tentang RTRW 2011, secara tegas ditetapkannya luasan RTH sebesar 30\% yang terdiri dari RTH Publik sebesar 20\% dan RTH Private sebesar $10 \%$. 


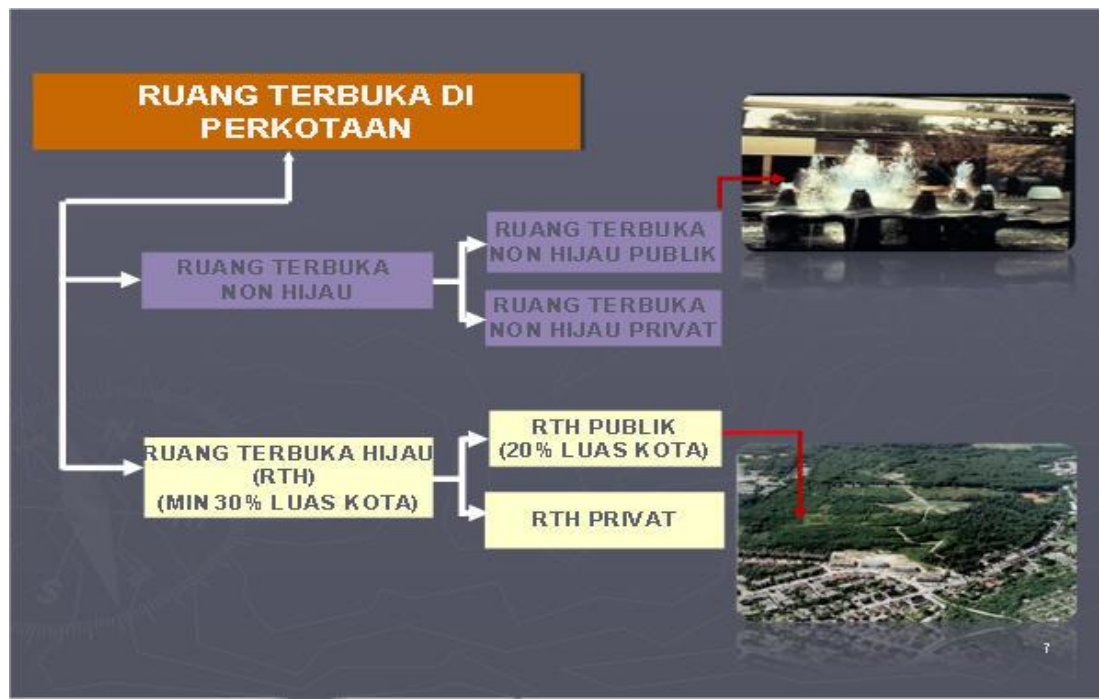

Gambar 1. Komposisi RTH di Kota menurut UU no.26/2007

Namun demikian sampai dengan saat ini, Jakarta hijau sangat sulit diwujudkan, terbukti dengan jumlah RTH di DKI Jakarta semakin menurun. Hal tersebut juga menunjukan lemahnya tata kota di DKI Jakarta, terutama dalam pengelolaan lahan dan tata kota dalam pembangunan kota, khususnya kota-kota besar yang mengalami pertumbuhan ekonomi sangat cepat seperti kota Jakarta ini.

Hingga saat ini pembangunan RTH masih menemui banyak kendala yang berdampak pada semakin menurunnya daya dukung lingkungan sehingga menimbulkan ketidaknyamanan kota akibat tata ruang yang salah. Adanya kebijakan antara pemerintah pusat dan pemerintah kota yang saling bertolak belakang., dimana di satu sisi mengakui kepentingan lingkungan hidup, namun disisi lainnya menekankan pada pentingnya sektor perkembangan perekonomian. Pada akhirnya, membuat Para pembuat keputusan menyakini bahwa pelaksanaan konsep keberlanjutan lingkungan justru akan merusak pertumbuhan ekonomi. Selain itu, Adanya pendapat yang menyatakan bahwa ruang terbuka hijau merupakan lahan cadangan untuk memenuhi tuntutan pertumbuhan kota yang mendesak dan dinilai tidak ekonomis menyebabkan semakin bertambahnya kendala dalam mempertahankan ruang terbuka hijau ini. Kendala tersebut terletak pada nilai lahan ruang terbuka hijau itu sendiri, baik secara sosial maupun ekonomi. Kendala ini akan berjalan seiring dengan belum mantapnya ketentuan legalitas yang menyangkut pengaturan, pengendalian dan pengawasan $\mathrm{RTH}$, sehingga tidak dapat terelakan bahwa daya dukung lingkungan akan semakin menurun yang berdampak pada bencana alam yang terjadi.

Dengan demikian dapat dikatakan penataan ruang yang salah secara langsung ataupun tidak akan berdampak pada penurunan kualitas lingkungan, sepertinya halnya 
kekurangan ruang terbuka hijau dalam suatu wilayah akan berdampak pada penurunan kualitas lingkungan yang mengakibatkan terjadinya berbagai bencana.

Menurut Soemarwoto (2001), daya dukung lingkungan pada hakekatnya adalah daya dukung lingkungan alamiah, yaitu berdasarkan biomas tumbuhan dan hewan yang dapat dikumpulkan dan ditangkap per satuan luas dan waktu di daerah itu. Sedangkan menurut Khanna (1999) daya dukung lingkungan hidup terbagi menjadi dua komponen, yaitu kapasitas penyediaan dan kapasitas tampung limbah.

Daya Dukung Lingkungan Hidup juga dapat diartikan sebagai kemampuan lingkungan hidup untuk mendukung prikehidupan manusia dan makhluk hidup lainnya. Semakin besar daya dukung lingkungan, maka akan semakin menunjang prikehidupan manusia di dalamnya dan kemungkinan terjadinya bencana alam pun akan semakin berkurang. Daya dukung suatu lingkungan dalam suatu wilayah dapat ditingkatkan, salah satunya adalah dengan ruang terbuka hijau. Ruang terbuka hijau dapat berfungsi dalam berbagai hal, seperti menyerap air tanah, mengurangi polusi, dan lain sebaginya. Dengan berbagai fungsi tersebut RTH dapat meminimalisir berbagai bencana yang secara langsung dapat dikatakan meningkatkan daya dukung lingkungan.

RTH pada dasarnya dapat terwujud dalam berbagai bentuk di suatu wilayah berdasarkan tujuan pembuatan RTH tersebut. Berdasarkan bobot kealamiannya, bentuk RTH dapat diklasifikasi menjadi:

a. Bentuk RTH alami (habitat liar/alami, kawasan lindung)

b. Bentuk RTH non alami atau RTH binaan (pertanian kota, pertamanan kota, lapangan olah raga, pemakaman, kebun bibit,dll)

Sedangkan, berdasarkan sifat dan karakter ekologisnya diklasifikasi menjadi:

a. Bentuk RTH kawasan (areal, non linear)

b. Bentuk RTH jalur (koridor, linear)

Dan berdasarkan penggunaan lahan atau kawasan fungsionalnya diklasifikasi menjadi:

a. RTH kawasan perdagangan

b. RTH kawasan perindustrian

c. RTH kawasan permukiman

d. RTH kawasan pertanian

e. RTH kawasan-kawasan khusus, seperti pemakaman, olah raga, alamiah,dll. 
Ruang terbuka hijau (RTH), baik RTH publik maupun RTH privat, memiliki fungsi utama (intrinsik) yaitu fungsi ekologis, dan fungsi tambahan (ekstrinsik) yaitu fungsi arsitektural, sosial, dan fungsi ekonomi. Dalam suatu wilayah perkotaan empat fungsi utama ini dapat dikombinasikan sesuai dengan kebutuhan, kepentingan, dan keberlanjutan kota. RTH berfungsi ekologis, yang menjamin keberlanjutan suatu wilayah kota secara fisik, harus merupakan satu bentuk RTH yang berlokasi, berukuran, dan berbentuk pasti dalam suatu wilayah kota, seperti RTH untuk per-lindungan sumberdaya penyangga kehidupan manusia dan untuk membangun jejaring habitat hidupan liar. RTH untuk fungsi-fungsi lainnya (sosial ekonomi, arsitektural) merupakan RTH pendukung dan penambah nilai kualitas lingkungan dan budaya kota tersebut, sehingga dapat berlokasi dan berbentuk sesuai dengan kebutuhan dan kepentingannya, seperti untuk ke-indahan, rekreasi, dan pendukung arsitektur kota.

Kota yang besar adalah kota yang syarat dengan krisis, tak terkecuali pada kota sebesar kota Jakarta. Krisis yang dialami bukan hanya krisis perencanaan melainkan krisis yang direncanakan. Dimana pada kota Jakarta nampak jelas terlihat tumpang tindih perencanaan pada daerah yang sama namun berbeda instansi. Terlebih lagi Jakarta merupakan Ibu kota dari Negara Indonesia akibatnya perekonomian berpusat pada kota ini yang mengakibatkan pertumbuhan penduduk menjadi pesat pula akibat banyak orang yang hijrah ke DKI Jakarta untuk mencari peruntungan rezeki mereka di kota ini.

Pertumbuhan penduduk yang pesat yakni sekitar $8 \%$ - 9\% pertahun mengakibatkan tingkat kebutuhan lahan juga semakin meningkat. Akibatnya, timbul berbagai kendala bagi pemerintah dalam membuat fasilitas umum, salah satunya adalah RTH. Dimana kendala ini terbentur pada minimnya lahan dan banyak lahan yang berubah fungsi sebagai lahan pemukiman guna menghadapi tuntutan pertumbuhan penduduk yang pesat, banyak ruang terbuka hijau yang telah dialih fungsikan menjadi lahan pemukiman maupun peruntukan lainnya yang dinilai memiliki nilai ekonomi yang lebih tinggi. Hal ini tentu saja menyebabkan penurunan daya dukung lingkungan yang mengakibatkan berbagai bencana alam yang terjadi belakangan ini. Selain itu, hal tersebut tidak sesuai dengan perencanaan kota Jakarta itu sendiri, dimana pada awalnya kota Jakarta memiliki target memiliki ruang terbuka hijau sebesar $13,84 \%$ dari seluruh luas wilayah DKI Jakarta.

Hal tersebut jelas menunjukan dimana sistem penataan kota tidak direncanakan secara terpadu dan menyeluruh dimana banyak aspek tidak dipertimbangkan dan hanya dinilai dari segi nilai ekonominya saja. Padahal, kekurangan ruang wilayah terbuka hijau 
pada akhirnya banyak memberikan banyak dampak negatif seperti kurangnya daya dukung lingkungan yang juga diiringi dengan penurunan tingkat kenyamanan kota akibat kepadatan kota.

RTH merupakan satu diantara strategi yang tepat untuk mengatasi permasalahan krisis lingkungan di atas. RTH perkotaan mempunyai manfaat kehidupan yang tinggi. Berbagai fungsi dapat dikaitkan dengan keberadaannya (fungsi ekologis, sosial, ekonomi, dan arsitektural) dan nilai estetika yang dimilikinya (obyek dan lingkungan) tidak hanya dapat dalam meningkatkan kualitas lingkungan dan untuk kelangsungan kehidupan perkotaan tetapi juga dapat menjadi nilai kebanggaan dan identitas kota. Untuk mendapatkan RTH yang fungsional dan estetik dalam suatu sistem perkotaan maka luas minimal, pola dan struktur, serta bentuk dan distribusinya harus menjadi pertimbangan dalam membangun dan mengembangkannya. Karakter ekologis, kondisi dan keinginan warga kota, serta arah dan tujuan pembangunan dan perkembangan kota merupakan determinan utama dalam menentukan besaran RTH fungsional ini.

Keberadaan RTH penting dalam mengendalikan dan memelihara integritas dan kualitas lingkungan. Pengendalian pembangunan wilayah perkotaan harus dilakukan secara proporsional dan berada dalam keseimbangan antara pembangunan dan fungsi-fungsi lingkungan. Kelestarian RTH suatu wilayah perkotaan harus disertai dengan ketersediaan dan seleksi tanaman yang sesuai dengan arah rencana dan rancangannya.

Meskipun demikian, pada kenyataanya RTH yang ada di wilayah DKI Jakarta jumlahnya semakin menurun setiap tahunnya. Hal tersebut dipengaruhi dan didorong oleh berbagai faktor yang akan coba Saya kaji. Selain itu pemanfaatan RTH yang tidak semestinya disertai perawatan dan pengawasan yang kurang optimal menyebabkan banyak RTH tidak dapat berfungsi sebagaimana mestinya.

Berbagai hal yang telah diungkapkan diatas mendorong untuk dilakukan penelitian dan evaluasi kuantitas dalam hal ini jumlah RTH dan kualitas dalam hal ini pemanfaatan dan kondisi ruang terbuka hijau yang ada di DKI Jakarta. Penelitian ini begitu penting untuk mengetahui sejauh mana Pemkot DKI Jakarta mementingkan adanya ruang terbuka hijau seperti perencanaan kota yang ada dan bagaimana manfaat dan kondisi ruang terbuka hijau itu sendiri, serta sejauh mana peluang dan kendala PEMDA DKI Jakarta dalam membuat dan mengembangkan $\mathrm{RTH}$. 


\section{METODA}

Dalam penelitian ini metode yang digunakan adalah metode pendekatan deskriptif yang bersifat survei. Pada Penelitian ini yang menjadi objek penelitian yaitu ruang terbuka hijau yang ada di setiap wilayah Administratif DKI Jakarta.

Populasi dalam penelitian ini adalah seluruh wilayah di DKI Jakarta.

Sampel yang digunakan dalam penelitian ini adalah purposive sampel yaitu metode pengambilan sampel yang tidak acak. Dalam hal ini sampel dipilih berdasarkan tujuan tertentu yaitu setiap bentuk ruang terbuka hijau (RTH) yang dikembangkan di setiap wilayah administratif di DKI Jakarta.

Teknik analisis data yang digunakan adalah analisis kualitatif. Teknik analisis data yang dimaksud dalam penelitian ini adalah analisis terhadap data, yang diperoleh dari pemda DKI Jakarta. Setelah itu, data akan dianalisis dan disesuaikan dengan keadaan yang sebenarnya di lapangan sehingga akan diperoleh suatu kebenaran dalam hasil penelitian. Dalam penelitian ini juga akan dilakukan pengamatan untuk mengetahui pemnfaatan dan kondisi pada setiap sample $\mathrm{RTH}$ yang diambil.

\section{HASIL PENELITIAN}

\section{Deskripsi Wilayah Penelitian}

pembagian luas wilayah administratif DKI Jakarta seperti tersaji pada Tabel 4.1 di bawah ini:

Tabel 1. Luas Wilayah Administratif DKI Jakarta

\begin{tabular}{|c|l|c|}
\hline \multirow{2}{*}{ NO. } & \multicolumn{1}{|c|}{ KOTAMADYA } & LUAS $\left.\mathbf{( k m}^{2}\right)$ \\
\hline 1 & Jakarta Selatan & 145,73 \\
\hline 2 & Jakarta Timur & 187,75 \\
\hline 3 & Jakarta Pusat & 48,2 \\
\hline 4 & Jakarta Barat & 126,15 \\
\hline 5 & Jakarta Utara & 141,88 \\
\hline 6 & Kepulauan Seribu & 11,81 \\
\hline \multicolumn{2}{|c|}{ Total Luas } & 661,52 \\
\hline
\end{tabular}

Sumber: Dinas Tata Kota DKI Jakarta

Di sebelah selatan dan timur Jakarta masih terdapat situ dengan luas sekitar 121,40 Ha. Kedua wilayah ini cocok untuk digunakan sebagai wilayah resapan air. Adapun wilayah 
Jakarta Barat memungkinkan dikembangkan sebagai wilayah perumahan. Kegiatan Industri banyak terdapat di Jakarta Utara dan Jakarta Timur, sedangkan untuk kegiatan usaha dan perkantoran banyak terdapat di Jakarta Barat, Jakarta Selatan dan Jakarta Pusat.

\section{Data Luas Ruang Terbuka Hijau di DKI Jakarta}

Luas RTH pada setiap Kotamadya DKI Jakarta berdasarkan Badan Survei Fisik Perkotaan secara umum dapat dilihat pada Tabel 4.3 di bawah ini:

Tabel 2. Luas RTH pada Wilayah Administratif DKI Jakarta

\begin{tabular}{|c|c|c|c|c|c|c|c|c|}
\hline No. & \multirow{2}{*}{ Kotamadya } & $\begin{array}{c}\text { Taman dan } \\
\text { Hutan Kota } \\
\left(\mathrm{km}^{2}\right)\end{array}$ & $\begin{array}{c}\text { Jalur } \\
\text { Hijau } \\
\text { jalan } \\
\left(\mathrm{km}^{2}\right)\end{array}$ & $\begin{array}{c}\text { Taman Bang. } \\
\text { Umum }\left(\mathrm{km}^{2}\right)\end{array}$ & $\begin{array}{c}\text { Tepian } \\
\text { Air }\left(\mathrm{km}^{2}\right)\end{array}$ & $\begin{array}{c}\text { Taman } \\
\text { Rekreas } \\
\mathrm{i}\left(\mathrm{km}^{2}\right)\end{array}$ & $\begin{array}{c}\text { RTH } \\
\text { Pemaka } \\
\text { man } \\
\left(\mathrm{km}^{2}\right)\end{array}$ & $\begin{array}{c}\text { Total } \\
\text { Luasa } \\
\mathrm{n} \mathrm{RTH} \\
\left(\mathrm{km}^{2}\right)\end{array}$ \\
\cline { 2 - 9 } \\
\hline & $\begin{array}{c}\text { Jakarta } \\
\text { Pusat }\end{array}$ & 5,0964 & 1,3632 & 1,0284 & 0,0309 & 0,1131 & 0,3794 & 8,0114 \\
\hline 2 & $\begin{array}{c}\text { Jakarta } \\
\text { Utara }\end{array}$ & 5,0423 & 0,7771 & 0,00725 & 0,02035 & & 0,8399 & 6,6869 \\
\hline 3 & $\begin{array}{c}\text { Jakarta } \\
\text { Barat }\end{array}$ & 3,304727 & 0,6141 & 0,0572 & 0,1533 & & 0,9107 & 5,0401 \\
\hline 4 & $\begin{array}{c}\text { Jakarta } \\
\text { Selatan }\end{array}$ & 9,00497 & 1,2586 & 0,212 & 0,1294 & 2 & 1,5014 & 14,107 \\
\hline 5 & $\begin{array}{c}\text { Jakarta } \\
\text { Timur }\end{array}$ & 7,667 & 1,6382 & 2,3853 & 0,2373 & 11,1032 & 1,7304 & 24,761 \\
\hline \multicolumn{2}{|c|}{ Total Luasan } & 30,115397 & 5,6512 & 3,69015 & 0,57125 & 13,2163 & 5,3618 & 58,606 \\
\hline
\end{tabular}

Sumber : Dinas Tata Kota DKI Jakarta

\section{Pengolahan Data}

Berdasarkan data Badan Survei Fisik Kota dan Dinas Tata Ruang Kota, serta survei langsung di lapangan menunjukan bahwa luas RTH pada setiap wilayah administratif sebagai berikut:

\begin{tabular}{|l|c|c|c|}
\hline KOTAMADYA & $\begin{array}{c}\text { LUAS } \\
\text { wilayah } \\
\left.\mathbf{( k m}^{2}\right)\end{array}$ & $\begin{array}{c}\text { luas } \\
\mathbf{R T H} \\
\left.\mathbf{( k m}^{2}\right)\end{array}$ & \% RTH \\
\hline $\begin{array}{l}\text { Jakarta } \\
\text { Selatan }\end{array}$ & 145,73 & 14,37 & $9,86 \%$ \\
\hline Jakarta Timur & 187,75 & 24,50 & $13,05 \%$ \\
\hline Jakarta Pusat & 48,2 & 8,24 & $17,20 \%$ \\
\hline Jakarta Barat & 126,15 & 5,40 & $4,24 \%$ \\
\hline
\end{tabular}




\begin{tabular}{|l|c|c|c|}
\hline KOTAMADYA & $\begin{array}{c}\text { LUAS } \\
\text { wilayah } \\
\mathbf{( k m}^{2} \mathbf{)}\end{array}$ & $\begin{array}{c}\text { luas } \\
\text { RTH } \\
\left.\mathbf{( k m}^{2}\right)\end{array}$ & \% RTH \\
\hline Jakarta Utara & 141,88 & 6,74 & $4,74 \%$ \\
\hline $\begin{array}{l}\text { Kepulauan } \\
\text { Seribu }\end{array}$ & 11,81 & & \\
\hline & 661,52 & 59,25 & $9,12 \%$ \\
\hline
\end{tabular}

\section{Hasil Penelitian}

RUTR dimana RTH yang direncanakan seharusnya sebesar $13,84 \%$ atau dapat di hitung seluas: Luas.RTH $=13,84 \%$ x L.DKI Jakarta $=13,84 \% \times 661,52 \mathrm{~km}^{2}=89,97 \mathrm{~km}^{2}$

Berdasarkan hasil survei di atas, dapat dinyatakan DKI Jakarta memiliki kekurangan RTH sebesar $59,25 \mathrm{~km}^{2}$ dari target $89,97 \mathrm{~km}^{2}$. Presentase kekurangan RTH pada DKI Jakarta dapat dihitung sebagai berikut:

$$
\begin{aligned}
\text { Kekurangan RTH } & =\frac{\text { Selisih Luas } R T H}{\text { Luas DKI Jakarta }} \times 100 \% \\
& =\frac{89,97-59,25}{661,57} \times 100 \% \\
& =\frac{30,72}{661,57} \times 100 \%=4,64 \%
\end{aligned}
$$

\section{Analisis Pemanfaatan RTH di Wilayah DKI Jakarta}

\section{Jakarta Utara}

Berdasarkan pengamatan yang dilakukan di lapangan. Analisis pemanfaatan RTH dibagi berdasarkan bentuk RTH yang dikembangkan di wilayah ini. Adapun bentuk- bentuk RTH yang dikembangkan di wilayah ini adalah:

1) RTH Pemukiman

Pembuatan RTH pemukiman ini bertujuan untuk penghijauan suatu wilayah pemukiman untuk meningkatkan kenyamanan penduduk. Karena hanya bertujuan sebagai penghijaun suatu wilayah, maka biasanya RTH pemukiman pada wilayah ini hanya dibuat pada lahan yang terbatas dan lebih kecil daripada taman. Namun demikian, karena banyak RTH pemukiman pada wilayah ini yang tidak terawat mengakibatkan RTH ini tidak dapat berfungsi sebagaimana semestinya. 
2) Taman

Taman pada wilayah ini kondisnya cukup terawat. Taman pada wilayah ini digunakan sebagai tempat interaksi sosial, dimana terdapat sarana bermain dan sarana olah raga. Beberapa taman juga dirancang khusus sebagai Taman rekreasi yang dilengkapi dengan berbagai fasilitas rekreasi yang menarik. Namun, beberapa Taman Interaksi sosial juga dimanfaat oleh para oknum yang tidak bertanggung jawab sebagai tempat berjualan.

3) SPBU RTH

SPBU RTH merupakan suatu SPBU seperti pada umumnya yang dimanfaatkan sebagai tempat pengisian bahan bakar kendaraan, tak terkecuali pada wilayah ini yang membedakannya adalah SPBU RTH dirancang khusus dengan penataan tanaman yang sedemikian rupa sehingga menjadikan tempat tersebut tidak hanya sebagai tempat pengisian bahan bakar, namun juga tempat penghijauan.

4) Hutan Kota

Hutan kota pada wilayah ini berdasarkan beberapa lokasi yang Saya survei hanya digunakan sebagai paru- paru kota dan konservasi resapan air, seperti yang terdapat pada kawasan Munjul dan Penjaringan, Jakarta Utara. Tidak ada sarana bermain, rekreasi, maupun fasilitas umum sebagaimana tersaji pada Gambar 3. di bawah ini:

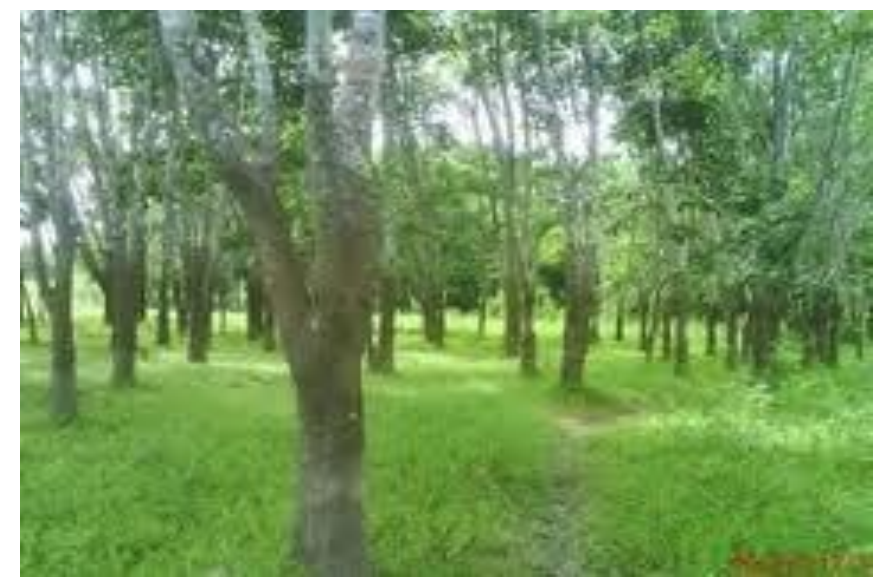

Gambar 3. Hutan Kota Kelurahan Munjul

5) Jalur Hijau Jalan

Tidak ada pemanfaatan khusus pada RTH tepian jalan atau yang biasa disebut juga jalur hijau jalan di wilayah ini. Jalur hijau jalan hanya digunakan sekedar sebagai penghijauan dan sarana memperindah kota. 


\section{6) TPU RTH}

Pada wilayah ini, TPU RTH agak berbeda dengan wilayah lainnya. Dimana semula direncanakan sebagai tempat pemakaman dan peresapan air, namun tidak demikian pada kebanyakan RTH di wilayah ini. RTH pada wilayah ini minim dengan wilayah peresapan air dan tidak semua lahan ditutupi tanaman. Lahan TPU banyak yang tertutup keramik atau tanah saja tanpa tanaman seperti terlihat pada TPU di kelurahan Pulau Kelapa sebagaimana tersaji pada Gambar 4. di bawah ini:

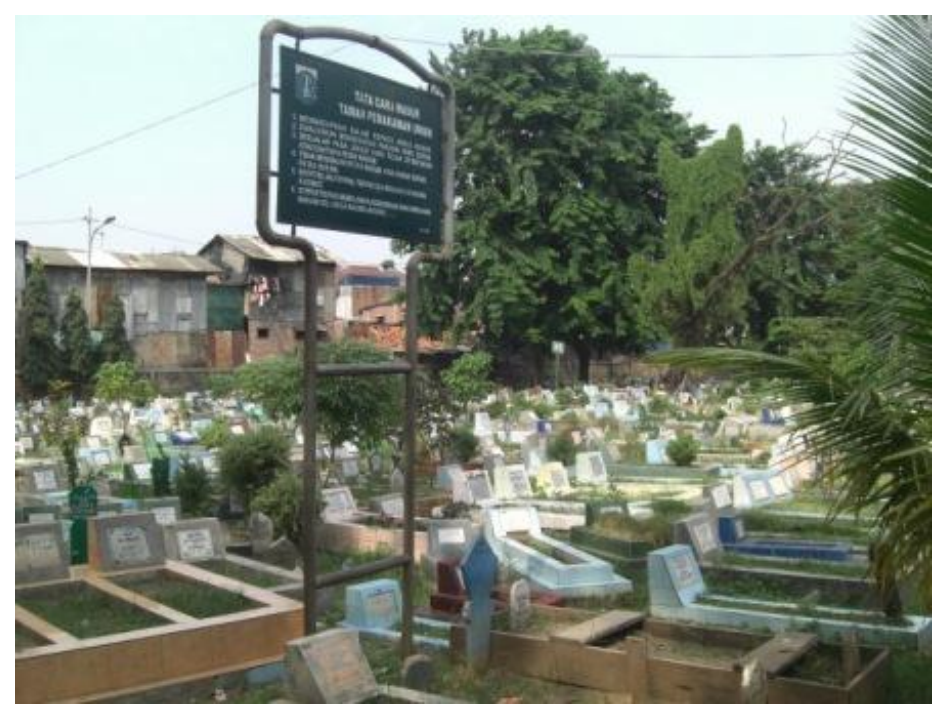

Gambar 4. TPU Kel. Pulau Kelapa

\section{Kondisi RTH di Wilayah DKI Jakarta}

Pada penelitian di lapangan, dengan mengambil satu titik dari setiap bentuk RTH pada setiap wilayah administratif untuk mengetahui secara umum bagaimana kondisi RTH yang sebenarnya di lapangan. Kondisi RTH di lapangan dianalisis berdasarkan komponenkomponen ideal suatu RTH. Adapun kondisi RTH di setiap wilayah administratif sebagai berikut: 


\section{Jakarta Utara}

Adapun contoh RTH di wilayah ini, sebagaimana tersaji pada Gambar di bawah ini:
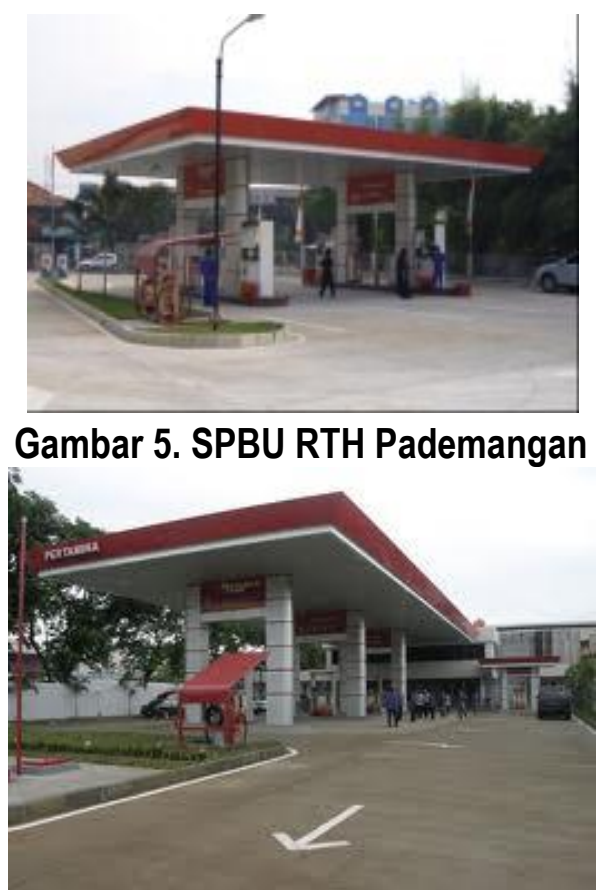

Gambar 6. SPBU RTH Kapuk

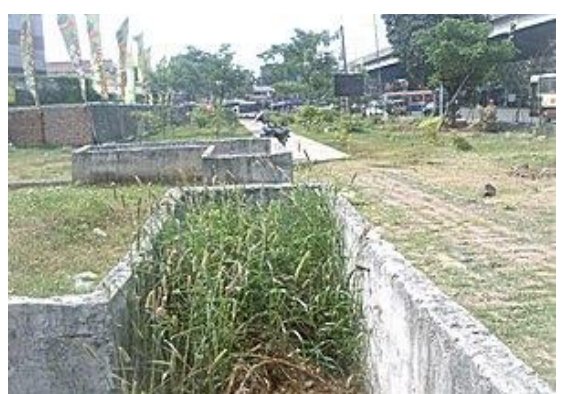

Gambar 7. RTH Pemukiman Padat Penduduk Tanjung Priok

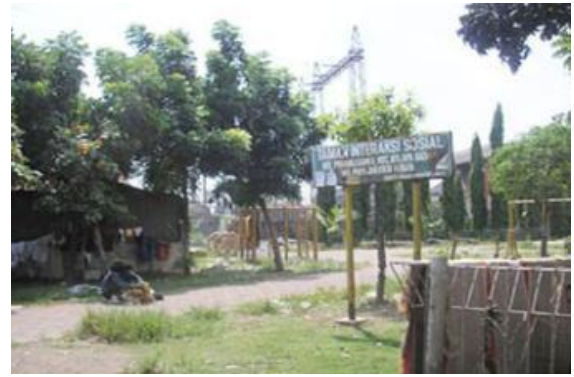

Gambar 8. RTH Pemukiman Padat Penduduk Wijaya Kusuma

Berdasarkan Gambar di atas yang didapat berdasarkan pengamatan di lapangan dapat disimpulkan secara umum bahwa kondisi RTH di wilayah Jakarta Utara sebagai berikut: 
Tabel 3. Kondisi RTH di Wilayah Jakarta Utara

\begin{tabular}{|c|c|c|c|c|c|c|c|c|c|c|}
\hline $\begin{array}{l}\text { KOTA } \\
\text { MADYA }\end{array}$ & NO & $\begin{array}{l}\text { NAMA RTH } \\
\text { (ALAMAT) }\end{array}$ & $\begin{array}{c}\text { Didirikan } \\
\text { pada } \\
\text { Lahan } \\
\text { Potensial }\end{array}$ & $\begin{array}{c}\text { Memenuhi } \\
\text { Luas } \\
\text { Minimum }\end{array}$ & $\begin{array}{c}\text { Memiliki } \\
\text { Daya } \\
\text { Dukung } \\
\text { Alami }\end{array}$ & $\begin{array}{l}\text { Ketercapaian } \\
\text { Tujuan } \\
\text { Pembuatan }\end{array}$ & $\begin{array}{c}\text { Memenuhi } \\
\text { Kesehatan \& } \\
\text { Kenyamanan }\end{array}$ & $\begin{array}{l}\text { Terdapat } \\
\text { Seleksi } \\
\text { Tanaman }\end{array}$ & $\begin{array}{l}\text { Konfi- } \\
\text { gurasi } \\
\text { Bentuk }\end{array}$ & $\begin{array}{l}\text { Memiliki } \\
\text { Fasilitas } \\
\text { Pendukung }\end{array}$ \\
\hline \multirow{8}{*}{$\begin{array}{l}\text { JAKARTA } \\
\text { UTARA }\end{array}$} & 1 & $\begin{array}{l}\text { Taman Kali } \\
\text { Sunter } \\
\end{array}$ & $\sqrt{ }$ & $\sqrt{ }$ & & & & & & \\
\hline & 2 & $\begin{array}{l}\text { RTH Pemukiman } \\
\text { Wijaya Kusuma }\end{array}$ & $\sqrt{ }$ & $\sqrt{ }$ & & & & & & \\
\hline & 3 & $\begin{array}{l}\text { SPBU RTH } \\
\text { Pademangan }\end{array}$ & $\sqrt{ }$ & $\sqrt{ }$ & & $\sqrt{ }$ & $\sqrt{ }$ & & $\sqrt{ }$ & \\
\hline & 4 & $\begin{array}{l}\text { Hutan Kota } \\
\text { Penjaringan }\end{array}$ & $\sqrt{ }$ & $\sqrt{ }$ & $\sqrt{ }$ & $\sqrt{ }$ & $\sqrt{ }$ & $\sqrt{ }$ & $\sqrt{ }$ & $\sqrt{ }$ \\
\hline & 5 & $\begin{array}{l}\text { Jalur Hijau Jl. } \\
\text { Pegangsaan }\end{array}$ & $\sqrt{ }$ & $\sqrt{ }$ & & $\sqrt{ }$ & $\sqrt{ }$ & $\sqrt{ }$ & & \\
\hline & 6 & $\begin{array}{l}\text { RTH Pemakaman } \\
\text { Sungai Bambu }\end{array}$ & $\sqrt{ }$ & $\sqrt{ }$ & & & & & & \\
\hline & 7 & $\begin{array}{l}\text { Taman Impian } \\
\text { Jaya Ancol }\end{array}$ & $\sqrt{ }$ & $\sqrt{ }$ & $\sqrt{ }$ & $\sqrt{ }$ & $\sqrt{ }$ & $\sqrt{ }$ & $\sqrt{ }$ & $\sqrt{ }$ \\
\hline & 8 & $\begin{array}{l}\text { RTH Bangunan } \\
\text { Umum }\end{array}$ & $\sqrt{ }$ & $\sqrt{ }$ & $\sqrt{ }$ & $\sqrt{ }$ & $\sqrt{ }$ & $\sqrt{ }$ & $\sqrt{ }$ & $\sqrt{ }$ \\
\hline
\end{tabular}

* beri tanda ceklist $(\sqrt{ })$ apabila syarat terpenuhi

\section{Jakarta Selatan}

Kondisi beberapa titik RTH secara langsung dapat dilihat sebagaimana tersaji pada Gambar di bawah ini:

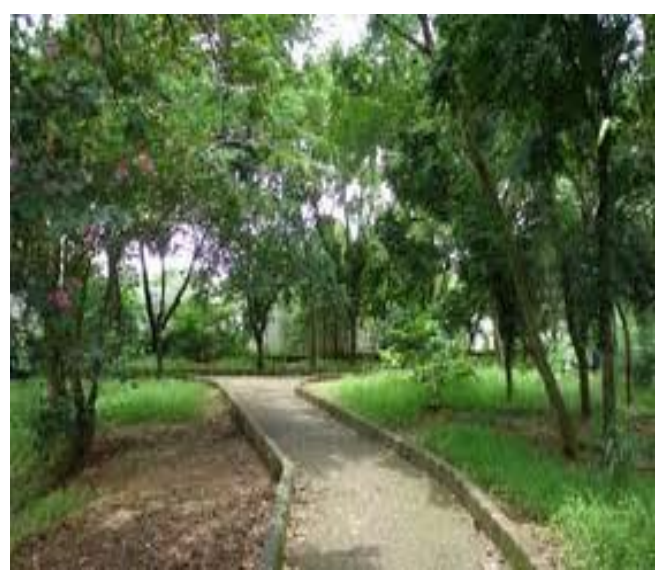

Gambar 9. Hutan Kota Jagakarsa 


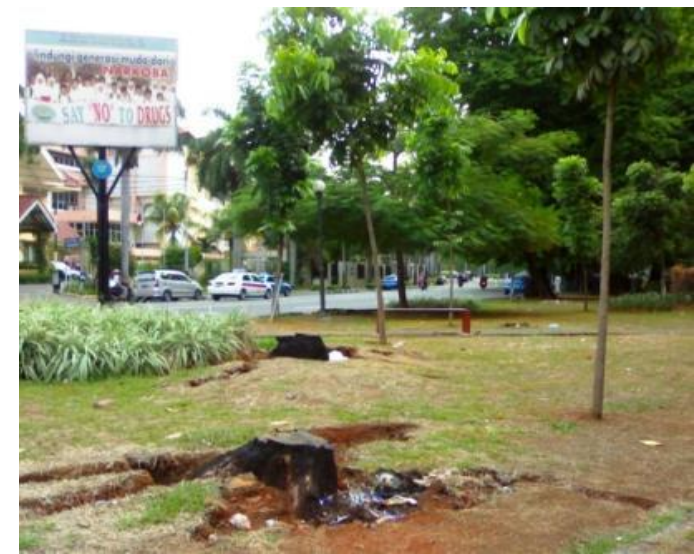

Gambar 10. RTH Tepian

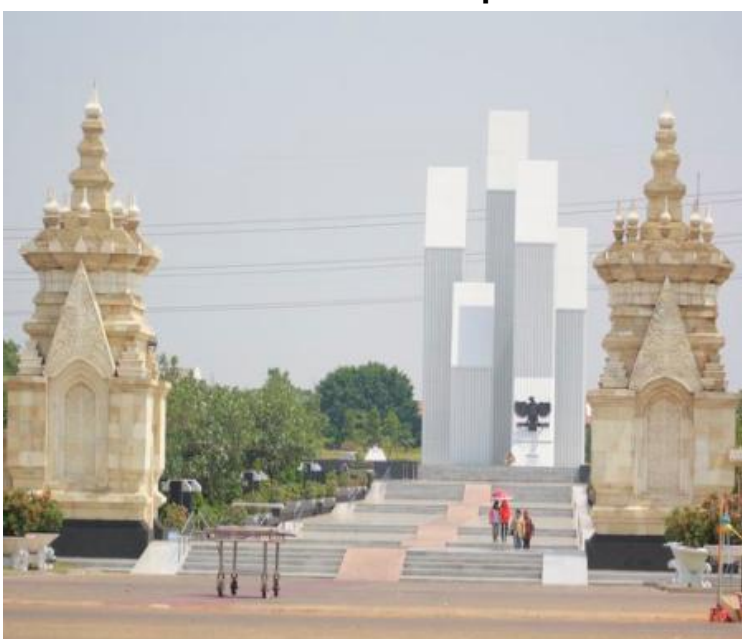

Gambar 11. TMP Kalibata

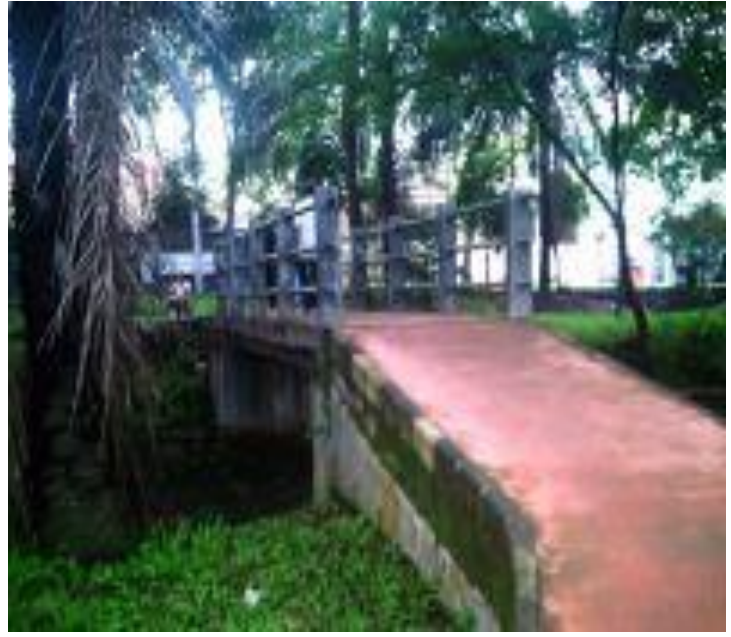

Gambar 12. Taman Tebet

Berdasarkan pengamatan langsung di lapangan dan Gambar di atas dapat disimpulkan secara umum bahwa kondisi RTH di wilayah Jakarta Selatan sebagai berikut: 
Tabel 4. Kondisi RTH di Wilayah Jakarta Selatan

\begin{tabular}{|c|c|c|c|c|c|c|c|c|c|c|}
\hline $\begin{array}{c}\text { KOTA } \\
\text { MADYA }\end{array}$ & NO. & $\begin{array}{l}\text { NAMA RTH } \\
\text { (ALAMAT) }\end{array}$ & $\begin{array}{l}\text { Didirikan } \\
\text { pada } \\
\text { Lahan } \\
\text { Potensial }\end{array}$ & $\begin{array}{l}\text { Memenuhi } \\
\text { Luas } \\
\text { Minimum }\end{array}$ & $\begin{array}{l}\text { Memiliki } \\
\text { Daya } \\
\text { Dukung } \\
\text { Alami }\end{array}$ & $\begin{array}{c}\text { Ketercapai } \\
\text { an Tujuan } \\
\text { Pembuata } \\
n\end{array}$ & $\begin{array}{c}\text { Memenuhi } \\
\text { Kesehatan \& } \\
\text { Kenyamanan }\end{array}$ & $\begin{array}{l}\text { Terdapat } \\
\text { Seleksi } \\
\text { Tanaman }\end{array}$ & $\begin{array}{l}\text { Konfi- } \\
\text { gurasi } \\
\text { Bentuk }\end{array}$ & $\begin{array}{c}\text { Memiliki } \\
\text { Fasilitas } \\
\text { Pen- } \\
\text { dukung }\end{array}$ \\
\hline \multirow{4}{*}{$\begin{array}{l}\text { JAKARTA } \\
\text { SELATAN }\end{array}$} & 1 & Taman Tebet & $\sqrt{ }$ & $\sqrt{ }$ & $\sqrt{ }$ & $\sqrt{ }$ & $\sqrt{ }$ & $\sqrt{ }$ & $\sqrt{ }$ & $\sqrt{ }$ \\
\hline & 2 & $\begin{array}{l}\text { RTH Pemukiman } \\
\text { Tebet }\end{array}$ & $\sqrt{ }$ & $\sqrt{ }$ & $\sqrt{ }$ & $\sqrt{ }$ & $\sqrt{ }$ & $\sqrt{ }$ & $\sqrt{ }$ & $\sqrt{ }$ \\
\hline & 3 & $\begin{array}{l}\text { SPBU RTH MT. } \\
\text { Haryono }\end{array}$ & $\sqrt{ }$ & $\sqrt{ }$ & $\sqrt{ }$ & $\sqrt{ }$ & $\sqrt{ }$ & $\sqrt{ }$ & $\sqrt{ }$ & $\sqrt{ }$ \\
\hline & 4 & $\begin{array}{l}\text { Hutan Kota } \\
\text { Jagakarsa }\end{array}$ & $\sqrt{ }$ & $\sqrt{ }$ & $\sqrt{ }$ & $\sqrt{ }$ & $\sqrt{ }$ & $\sqrt{ }$ & $\sqrt{ }$ & $\sqrt{ }$ \\
\hline & 5 & $\begin{array}{l}\text { Jalur Hijau Jl. Gatot } \\
\text { Subroto }\end{array}$ & $\sqrt{ }$ & $\sqrt{ }$ & & & & & & \\
\hline & 6 & $\begin{array}{l}\text { RTH Pemakaman } \\
\text { Kalibata }\end{array}$ & $\sqrt{ }$ & $\sqrt{ }$ & $\sqrt{ }$ & $\sqrt{ }$ & $\sqrt{ }$ & $\sqrt{ }$ & $\sqrt{ }$ & $\sqrt{ }$ \\
\hline & 7 & $\begin{array}{l}\text { Taman Rekreasi } \\
\text { Ragunan }\end{array}$ & $\sqrt{ }$ & $\sqrt{ }$ & $\sqrt{ }$ & $\sqrt{ }$ & $\sqrt{ }$ & $\sqrt{ }$ & $\sqrt{ }$ & $\sqrt{ }$ \\
\hline & 8 & $\begin{array}{l}\text { RTH Bangunan } \\
\text { Umum }\end{array}$ & $\sqrt{ }$ & $\sqrt{ }$ & $\sqrt{ }$ & $\sqrt{ }$ & $\sqrt{ }$ & $\sqrt{ }$ & $\sqrt{ }$ & $\sqrt{ }$ \\
\hline & 9 & $\begin{array}{l}\text { Kebun Bibit } \\
\text { Ragunan } \\
\end{array}$ & $\sqrt{ }$ & $\sqrt{ }$ & $\sqrt{ }$ & $\sqrt{ }$ & $\sqrt{ }$ & $\sqrt{ }$ & v & $\sqrt{ }$ \\
\hline & 10 & Lapangan Golf & $\sqrt{ }$ & $\sqrt{ }$ & $\sqrt{ }$ & $\sqrt{ }$ & $\sqrt{ }$ & $\sqrt{ }$ & v & $\sqrt{ }$ \\
\hline
\end{tabular}

* beri tanda ceklist $(\sqrt{ })$ apabila syarat terpenuhi

\section{Jakarta Pusat}

Gambaran Kondisi RTH tersebut secara umum dapat terlihat sebagaimana tersaji pada

Gambar di bawah ini:

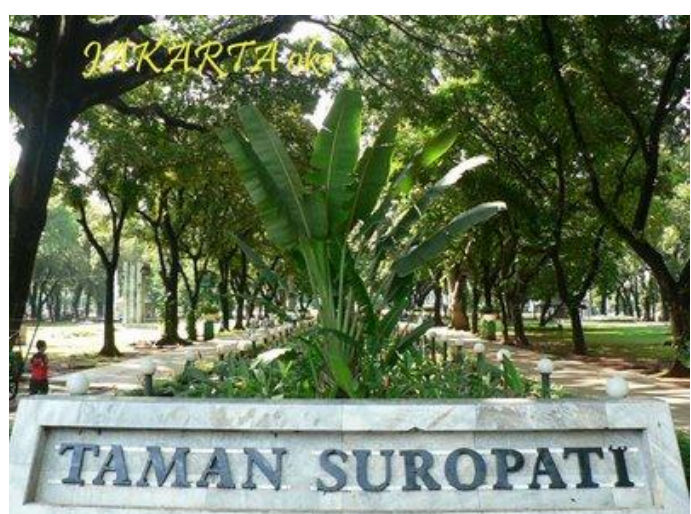

Gambar 13. Taman Suropati 


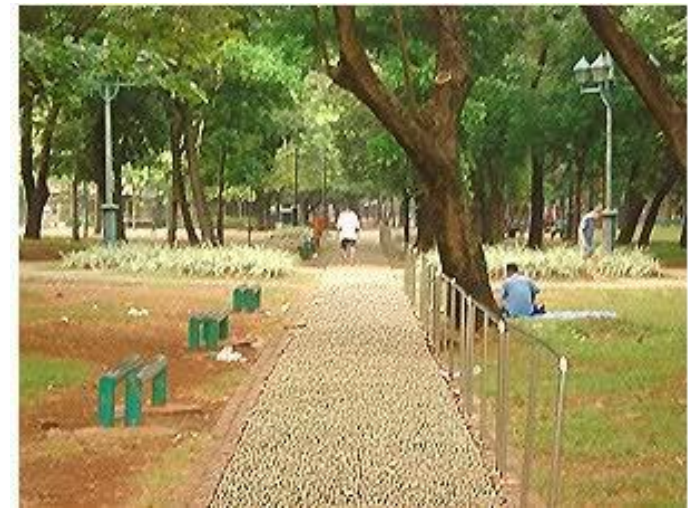

\section{Gambar 14. Taman Monas}

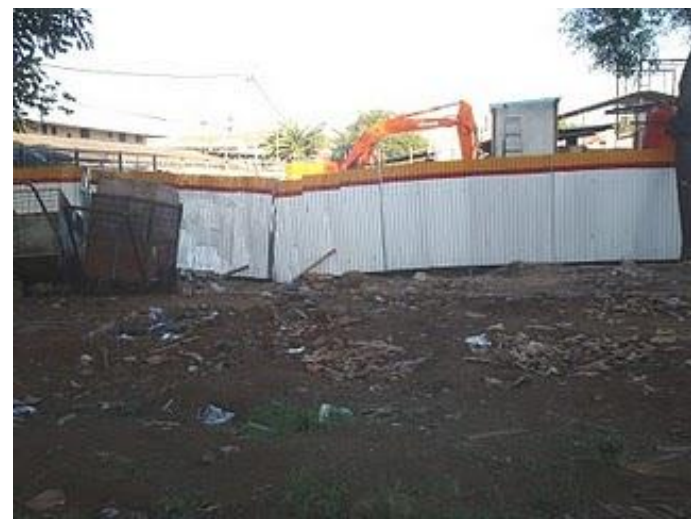

Gambar 15. RTH Pemukiman JI. A. Yani

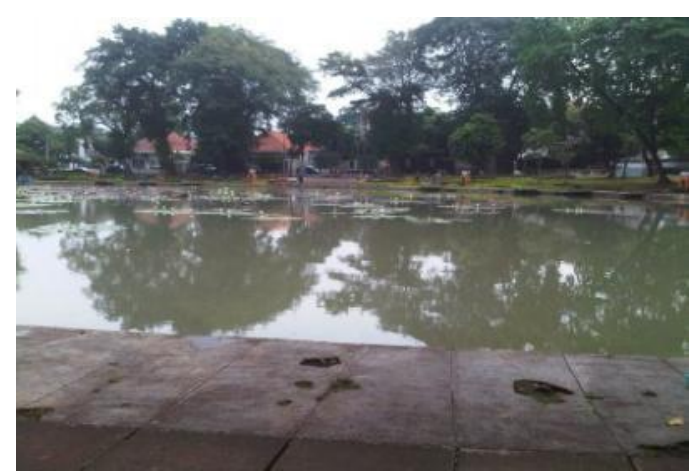

Gambar 16. Taman Situ Lembang

Berdasarkan pengamatan langsung di lapangan dan Gambar di atas dapat disimpulkan secara umum bahwa kondisi RTH di wilayah Jakarta Pusat sebagai berikut: 
Tabel 5. Kondisi RTH di Wilayah Jakarta Pusat

\begin{tabular}{|c|c|c|c|c|c|c|c|c|c|c|}
\hline $\begin{array}{l}\text { KOTA } \\
\text { MADYA }\end{array}$ & NO. & $\begin{array}{l}\text { NAMA RTH } \\
\text { (ALAMAT) }\end{array}$ & $\begin{array}{l}\text { Didirikan } \\
\text { pada } \\
\text { Lahan } \\
\text { Potensial }\end{array}$ & $\begin{array}{l}\text { Memenuhi } \\
\text { Luas } \\
\text { Minimum }\end{array}$ & $\begin{array}{l}\text { Memiliki } \\
\text { Daya } \\
\text { Dukung } \\
\text { Alami }\end{array}$ & $\begin{array}{l}\text { Ketercapaian } \\
\text { Tujuan } \\
\text { Pembuatan }\end{array}$ & $\begin{array}{c}\text { Memenuhi } \\
\text { Kesehatan \& } \\
\text { Kenyamanan }\end{array}$ & $\begin{array}{c}\text { Terdapat } \\
\text { Seleksi } \\
\text { Tanaman }\end{array}$ & $\begin{array}{l}\text { Konfigurasi } \\
\text { Bentuk }\end{array}$ & $\begin{array}{c}\text { Memiliki } \\
\text { Fasilitas } \\
\text { Pendukun } \\
\mathrm{g}\end{array}$ \\
\hline \multirow{8}{*}{$\begin{array}{l}\text { JAKARTA } \\
\text { PUSAT }\end{array}$} & 1 & $\begin{array}{l}\text { Taman Situ } \\
\text { Lembang }\end{array}$ & $\sqrt{ }$ & $\sqrt{ }$ & $\sqrt{ }$ & & & & $\sqrt{ }$ & \\
\hline & 2 & $\begin{array}{l}\text { RTH Pemukiman Jl. } \\
\text { A. Yani }\end{array}$ & $\sqrt{ }$ & $\sqrt{ }$ & & & & & & \\
\hline & 3 & SPBU RTH Cikini & $\sqrt{ }$ & $\sqrt{ }$ & & $\sqrt{ }$ & & & & \\
\hline & 4 & $\begin{array}{l}\text { Hutan Kota Masjid } \\
\text { Meutia }\end{array}$ & $\sqrt{ }$ & $\sqrt{ }$ & $\sqrt{ }$ & $\sqrt{ }$ & $\sqrt{ }$ & $\sqrt{ }$ & $\sqrt{ }$ & $\sqrt{ }$ \\
\hline & 5 & $\begin{array}{l}\text { Jalur Hijau JI. Imam } \\
\text { Bonjol }\end{array}$ & $\sqrt{ }$ & $\sqrt{ }$ & $\sqrt{ }$ & $\sqrt{ }$ & $\sqrt{ }$ & $\sqrt{ }$ & $\sqrt{ }$ & $\sqrt{ }$ \\
\hline & 6 & $\begin{array}{l}\text { RTH Pemakaman } \\
\text { Menteng Pulo }\end{array}$ & $\sqrt{ }$ & $\sqrt{ }$ & $\sqrt{ }$ & $\sqrt{ }$ & & & & \\
\hline & 7 & Taman MONAS & $\sqrt{ }$ & $\sqrt{ }$ & $\sqrt{ }$ & $\sqrt{ }$ & & $\sqrt{ }$ & $\sqrt{ }$ & $\sqrt{ }$ \\
\hline & 8 & $\begin{array}{l}\text { RTH Bangunan } \\
\text { Umum }\end{array}$ & $\sqrt{ }$ & $\sqrt{ }$ & $\sqrt{ }$ & $\sqrt{ }$ & $\sqrt{ }$ & $\sqrt{ }$ & $\sqrt{ }$ & $\sqrt{ }$ \\
\hline
\end{tabular}

${ }^{*}$ beri tanda ceklist $(\sqrt{ })$ apabila syarat terpenuhi

Adapun Gambaran beberapa kondisi RTH di wilayah ini dapat terlihat pada Gambar di bawah ini:
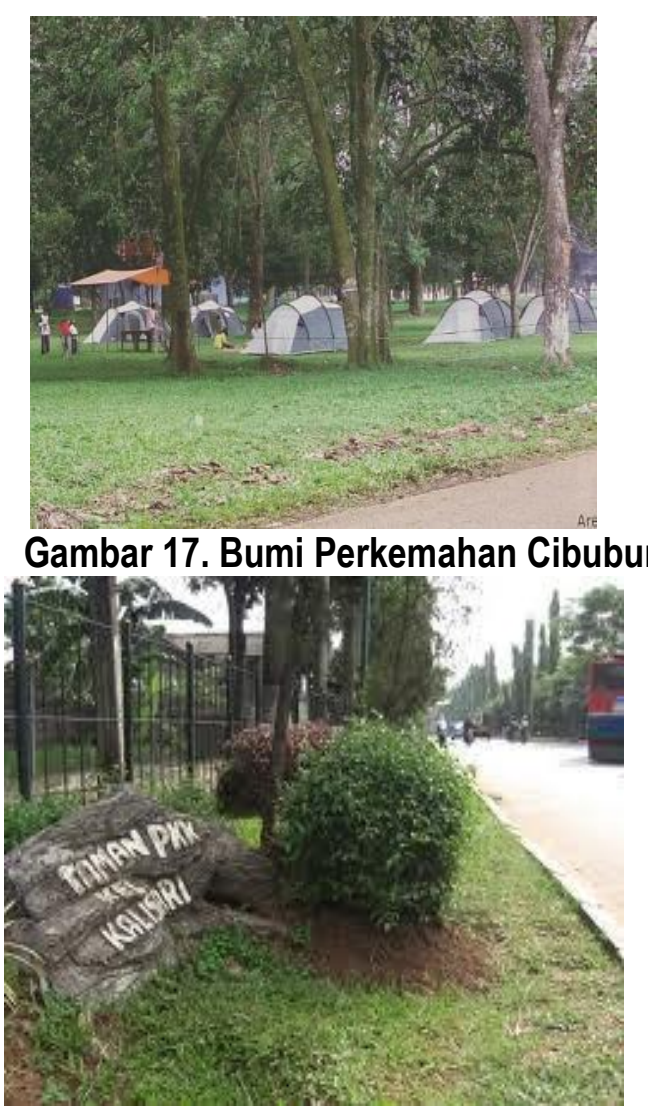

Gambar 18. RTH Pemukiman Cakung 


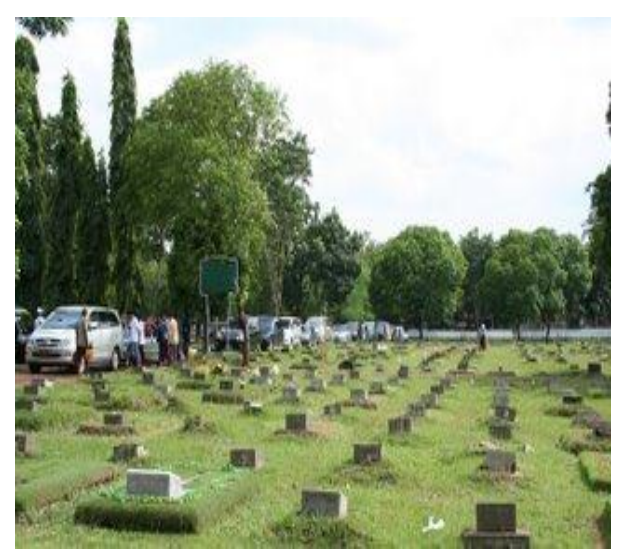

Gambar 19. TPU Pondok Rangon

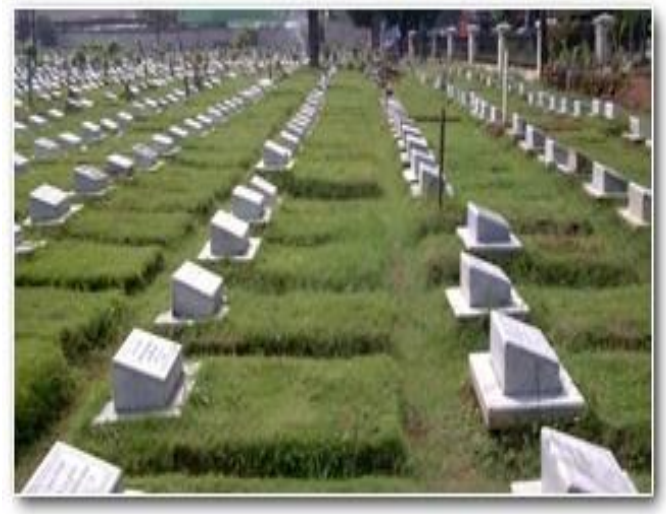

Gambar 20. TPU Utan Kayu

Berdasarkan pengamatan langsung di lapangan dan Gambar di atas dapat disimpulkan secara umum bahwa kondisi RTH di wilayah JakartaTimur sebagai berikut :

Tabel 6. Kondisi RTH di Wilayah JakartaTimur

\begin{tabular}{|c|c|c|c|c|c|c|c|c|c|c|}
\hline $\begin{array}{c}\text { KOTA } \\
\text { MADYA }\end{array}$ & NO. & $\begin{array}{c}\text { NAMA RTH } \\
\text { (ALAMAT) }\end{array}$ & $\begin{array}{l}\text { Didirikan } \\
\text { pada } \\
\text { Lahan } \\
\text { Potensial }\end{array}$ & $\begin{array}{l}\text { Memenuhi } \\
\text { Luas } \\
\text { Minimum }\end{array}$ & $\begin{array}{l}\text { Memiliki } \\
\text { Daya } \\
\text { Dukung } \\
\text { Alami }\end{array}$ & $\begin{array}{c}\text { Ketercapaian } \\
\text { Tujuan } \\
\text { Pembuatan }\end{array}$ & $\begin{array}{c}\text { Memenuhi } \\
\text { Kesehatan \& } \\
\text { Kenyamanan }\end{array}$ & $\begin{array}{l}\text { Terdapat } \\
\text { Seleksi } \\
\text { Tanaman }\end{array}$ & $\begin{array}{l}\text { Konfi- } \\
\text { gurasi } \\
\text { Bentuk }\end{array}$ & $\begin{array}{c}\text { Memiliki } \\
\text { Fasilitas } \\
\text { Pendu- } \\
\text { kung }\end{array}$ \\
\hline $\begin{array}{l}\text { JAKARTA } \\
\text { TIMUR }\end{array}$ & 1 & $\begin{array}{l}\text { RTH } \\
\text { Pemukiman }\end{array}$ & $\sqrt{ }$ & $\sqrt{ }$ & & $\sqrt{ }$ & & & & \\
\hline & & Cakung & & & & & & & & \\
\hline & 2 & $\begin{array}{l}\text { TPU Pondok } \\
\text { Rangon }\end{array}$ & $\sqrt{ }$ & $\sqrt{ }$ & $\sqrt{ }$ & $\sqrt{ }$ & $\sqrt{ }$ & $\sqrt{ }$ & $\sqrt{ }$ & $\sqrt{ }$ \\
\hline & 3 & $\begin{array}{l}\text { Bumi } \\
\text { Perkemahan } \\
\text { Cibubur }\end{array}$ & $\sqrt{ }$ & $\sqrt{ }$ & $\sqrt{ }$ & $\sqrt{ }$ & $\sqrt{ }$ & $\sqrt{ }$ & $\sqrt{ }$ & $\sqrt{ }$ \\
\hline & 4 & $\begin{array}{l}\text { Lapangan Golf } \\
\text { Rawamngun }\end{array}$ & $\sqrt{ }$ & $\sqrt{ }$ & $\sqrt{ }$ & $\sqrt{ }$ & $\sqrt{ }$ & $\sqrt{ }$ & $\sqrt{ }$ & $\sqrt{ }$ \\
\hline & 5 & $\begin{array}{l}\text { Taman Mini } \\
\text { Indonesia Indah }\end{array}$ & $\sqrt{ }$ & $\sqrt{ }$ & $\sqrt{ }$ & $\sqrt{ }$ & $\sqrt{ }$ & $\sqrt{ }$ & $\sqrt{ }$ & $\sqrt{ }$ \\
\hline & 6 & $\begin{array}{l}\text { SPBU RTH } \\
\text { Rawamangun }\end{array}$ & $\sqrt{ }$ & $\sqrt{ }$ & $\sqrt{ }$ & $\sqrt{ }$ & $\sqrt{ }$ & $\sqrt{ }$ & $\sqrt{ }$ & $\sqrt{ }$ \\
\hline
\end{tabular}

* beri tanda ceklist $(\sqrt{ })$ apabila syarat terpenuhi 


\section{Jakarta Barat}

Kondisi beberapa RTH di wilayah ini dapat dilihat pada Gambar di bawah ini:

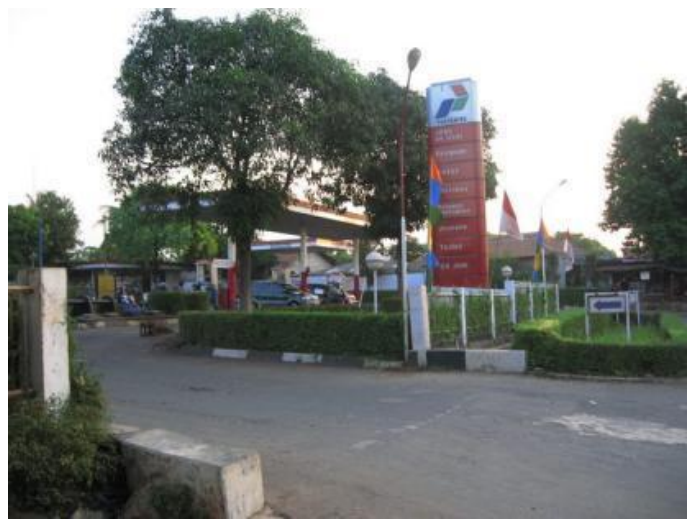

Gambar 21. RTH Pemukiman Kebun Jeruk

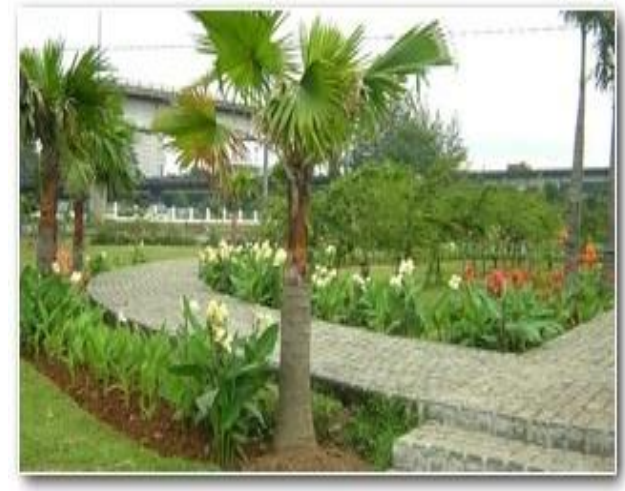

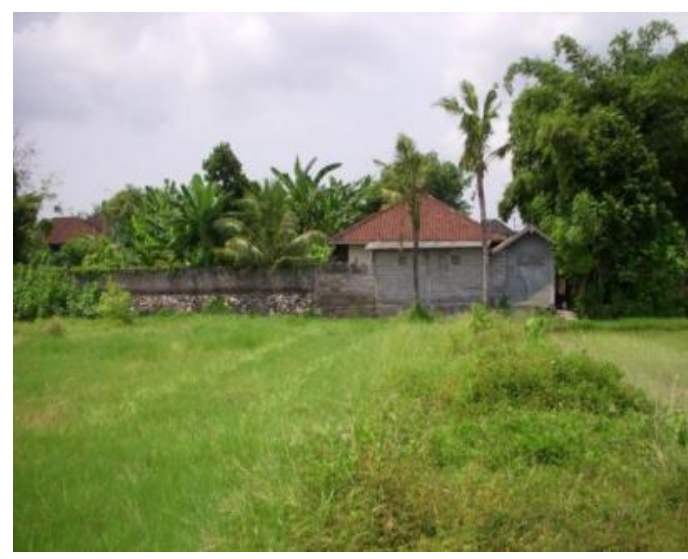

Gambar 22. SPBU RTH Joglo

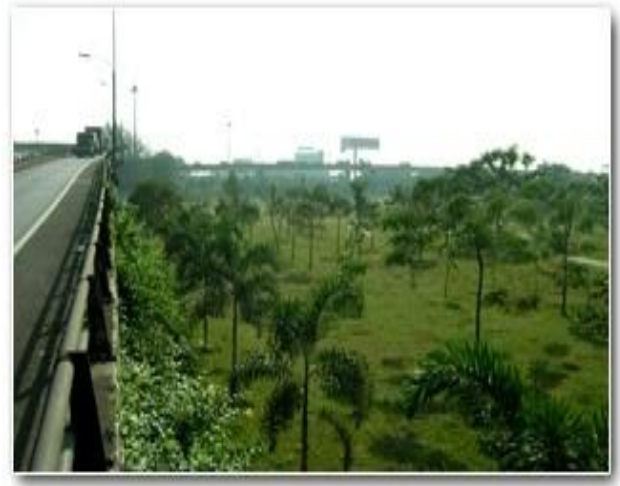

\section{Gambar 23. Taman Asean}

Berdasarkan pengamatan langsung di lapangan dan Gambar di atas dapat disimpulkan secara umum bahwa kondisi RTH di wilayah Jakarta Barat sebagai berikut :

Tabel 7. Kondisi RTH di Wilayah Jakarta Barat

\begin{tabular}{|c|c|c|c|c|c|c|c|c|c|c|}
\hline $\begin{array}{l}\text { KOTA } \\
\text { MADYA }\end{array}$ & NO. & $\begin{array}{l}\text { NAMA RTH } \\
\text { (ALAMAT) }\end{array}$ & $\begin{array}{l}\text { Didirikan } \\
\text { pada Lahan } \\
\text { Potensial }\end{array}$ & $\begin{array}{l}\text { Memenuhi } \\
\text { Luas } \\
\text { Minimum }\end{array}$ & $\begin{array}{c}\text { Memiliki } \\
\text { Daya } \\
\text { Dukung } \\
\text { Alami }\end{array}$ & $\begin{array}{l}\text { Ketercapaian } \\
\text { Tujuan } \\
\text { Pembuatan }\end{array}$ & $\begin{array}{c}\text { Memenuhi } \\
\text { Kesehatan \& } \\
\text { Kenyamanan }\end{array}$ & $\begin{array}{c}\text { Terdapat } \\
\text { Seleksi } \\
\text { Tanaman }\end{array}$ & $\begin{array}{l}\text { Konfigur } \\
\text { asi } \\
\text { Bentuk }\end{array}$ & $\begin{array}{c}\text { Memiliki } \\
\text { Fasilitas } \\
\text { Penduk } \\
\text { ung }\end{array}$ \\
\hline \multirow{6}{*}{$\begin{array}{l}\text { JAKARTA } \\
\text { BARAT }\end{array}$} & 1 & Taman Asean & $\sqrt{ }$ & $\sqrt{ }$ & $\sqrt{ }$ & $\sqrt{ }$ & $\sqrt{ }$ & $\sqrt{ }$ & $\sqrt{ }$ & $\sqrt{ }$ \\
\hline & 2 & $\begin{array}{l}\text { RTH Pemukiman } \\
\text { Kebun Jeruk }\end{array}$ & & $\sqrt{ }$ & & & & & & \\
\hline & 3 & SPBU RTH Joglo & $\sqrt{ }$ & $\sqrt{ }$ & & $\sqrt{ }$ & $\sqrt{ }$ & & $\sqrt{ }$ & \\
\hline & 4 & $\begin{array}{l}\text { Hutan Kota } \\
\text { Srengseng }\end{array}$ & $\sqrt{ }$ & $\sqrt{ }$ & $\sqrt{ }$ & $\sqrt{ }$ & $\sqrt{ }$ & $\sqrt{ }$ & $\sqrt{ }$ & $\sqrt{ }$ \\
\hline & 5 & $\begin{array}{l}\text { RTH } \\
\text { Pemakaman } \\
\text { Petamburan }\end{array}$ & $\sqrt{ }$ & $\sqrt{ }$ & $\sqrt{ }$ & $\sqrt{ }$ & $\sqrt{ }$ & $\sqrt{ }$ & $\sqrt{ }$ & $\sqrt{ }$ \\
\hline & 6 & $\begin{array}{l}\text { RTH Bangunan } \\
\text { Umum }\end{array}$ & $\sqrt{ }$ & $\sqrt{ }$ & $\sqrt{ }$ & $\sqrt{ }$ & $\sqrt{ }$ & $\sqrt{ }$ & $\sqrt{ }$ & $\sqrt{ }$ \\
\hline
\end{tabular}

* beri tanda ceklist $(\sqrt{ })$ apabila syarat terpenuhis 


\section{Analisis Upaya Pemerintah dalam Meningkatkan RTH}

Berdasarkan penelitian dan pengamatan di lapangan yang dilakukan dapat ditarik beberapa kesimpulan sejauh mana upaya yang telah dilakukan pemerintah dalam meningkatkan RTH di wilayah DKI Jakarta sesuai dengan target yang telah ditetapkan hingga Juni 2011. Beberapa upaya tersebut diantaranya:

a. Pengembalikan 12 stasiun pengisian bahan bakar umum (SPBU) di jalur hijau menjadi taman kota. Total luas lahan RTH dari pembongkaran Ke-12 SPBU tersebut mencapai 18.458 meter persegi atau hanya 1,8 hektar. Ke-12 SPBU yang akan dijadikan RTH yaitu SPBU Jalan Yos Sudarso, Jakarta Utara dengan luas 2.000 meter persegi, SPBU Jalan Pakubuwono Sisi Barat, Jakarta Selatan seluas 3.600 meter persegi dan SPBU lainnya.

b. Mempertahankan RTH yang sudah ada melalui refungsionalisasi, pengamanan dan sosialisasi

c. Mendorong pemanfaatan RTH private secara lebih optimal dan inovatif seperti penggunaan roof garden, wall garden, peningkatan konsistensi perijinan, dst.

d. Melakukan berbagai penyuluhan akan pentingnya RTH untuk meningkatkan apresiasi RTH dalam mengembangkan dan melestarikan RTH

e. Pembelian lahan untuk dijadikan RTH

f. Peremajaan kawasan permukiman kumuh dengan merelokasinya ke Rusun, dengan jumlah keluarga pada permukiman tersebut sebanyak 73.673 keluarga

g. Merefungsionalisasi kawasan pedagang kaki lima menjadi kawasan RTH

\section{Analisis Kendala Pengembangan RTH di DKI Jakarta}

Berdasarkan data yang dihimpun dan analisis di lapangan, secara umum dapat ditarik beberapa faktor penyebab berkurangnya RTH dalam suatu wilayah. Faktor- faktor tersebut antara lain:

a. Kurangnya koordinasi antara sejumlah lembaga administrasi yang bertanggung jawab untuk ruang terbuka hijau kota Jakarta. Provinsi Jakarta memiliki sejumlah lembaga yang bertanggung jawab hanya untuk ruang terbuka hijau kota dan tanggung jawab tersebut sering tumpang tindih antara Dinas Pertamanan, Dinas Kehutanan dan Kantor Pelayanan Pemakaman. 
b. Dari hasil kajian Peraturan Daerah Nomor 9 tahun 1982 tentang struktur organisasi dinas pertamanan DKI Jakarta diketahui masih perlu disempurnakan. yaitu adanya ketidakjelasan instansi pengelola rekreasi ruang luar, padahal rekreasi ruang luar termasuk dalam bagian dari ruang terbuka hijau kota. Hal ini akan menyulitkan pelaksanaan pengembangan dan pembinaannya. Hal lainnya adalah berkaitan dengan masalah kebijakan instansi pengelola ruang terbuka hijau di tingkat kecamatan yang hingga saat ini ditemui adanya ketidakjelasan tugas dan kewajiban aparat yang ada baik dari segi kualitas/kuantitas personil, padahal wadah dan aparat dilingkungan ini merupakan ujung tombak.

c. Belum tersedianya data pokok atau pusat informasi yang dapat mengindentifikasi terjadinya perusakan lingkungan akibat pembangunan kota

d. Kurangnya kemampuan aparatur pemerintahan di bidang ruang terbuka hijau

e. Terbatasnya sarana atau peralatan untuk menyelidik dan mencari bukti adanya kerusakan ruang terbuka hijau

f. Belum serasinya kerjasama antar instansi dalam melaksanakan pembangunan ruang terbuka hijau yang akibatnya banyak berpengaruh terhadap lingkungan

g. Belum adanya petunjuk teknis dari penjabaran Peraturan Menteri Dalam Negeri Nomor 1 Tahun 2007 Tentang Penataan Ruang Terbuka Hijau Kawasan Perkotaan.

h. Belum adanya model sistem informasi lahan, dan sistem informasi pemetaan yang akurat yang dengan mudah dapat memonitor secara cepat beberapa jumlah ruang terbuka hijau yang ada, beberapa jumlah yang terhapus, dan informasi lainnya yang sangat diperlukan bagi "pengambil keputusan" serta kebutuhan informasi lainnya. Sistem ini akan sangat diperlukan sekali untuk pengelolaan dari instansi-instansi yang terkait mulai saat proses perencanaan, pelaksanaan, monitoring hingga evaluasi dan pengendaliannya dalam rangka pengambilan keputusan,

i. Kekuasaan peradilan tidak cukup independen. Walaupun undang-undang tentang Pengelolaan Lingkungan Hidup no 23 tahun 1997 telah di sahkan, namun penerapan keputusan peradilan terhadap pengrusakan Ruang Terbuka Hijau tidak selalu berhasil. Hal ini dikarenakan pemahaman dan pengalaman para hakim terhadap eksistensi ruang terbuka hijau masih sangat terbatas.

j. Masih adanya peruntukan RTH yang dimanfaatkan untuk kegiatan non RTH secara illegal 
k. Ketersediaan lahan yang semakin menipis ditambah peningkatan aktivitas ekonomi Jakarta menyebabkan harga tanah semakin tinggi

I. Terbatasnya Sumber Daya Pemerintah dan masih belum terselesaikannya permasalahan transportasi dan banjir di Jakarta yang membutuhkan anggaran biaya yang sangat besar

m. Rendahnya apresiasi masyarakat terhadap keberadaan taman, jalur-jalur hijau dan tanaman - tanaman penghijauan yang ada; misalnya dalam Pengembangan Taman Monas dan Taman Stadion Menteng;

n. Distribusi RTH yang kurang merata di Wilayah Provinsi DKI Jakarta.

\section{Analisis Peluang Pengembangan RTH di DKI Jakarta}

Dalam kenyataannya pembangunan dan pengembangan RTH di wilayah DKI Jakarta menemui banyak kendala, namun juga terdapat banyak peluang dalam membangun, maupun mengembangkannya. Peluang tersebut antara lain:

a. Semakin buruknya kondisi dan keseimbangan lingkungan di wilayah DKI Jakarta pada akhirnya membuat Pemerintah semakin memantapkan akan pentingnya pembangunan dan pengembangan RTH dengan memantapkan legalitas RTH

b. Mulai dibuatnya berbagai peraturan yang meperkuat legalitas pembangunan, maupun pengembangan RTH di DKI Jakarta

c. Banyak lahan potensial di wilayah DKI Jakarta yang dapat dikembangkan menjadi ruang terbuka hijau yang dapat disesuaikan dengan tanaman yang dapat dikembangkan di wilayah tersebut

d. Potensi lainnya untuk menambah RTH di Propinsi DKI Jakarta adalah dengan melakukan refungsionalisasi lahan $\mathrm{RTH}$ yang merupakan aset Pemerintah Provinsi DKI Jakarta tetapi digunakan untuk kegiatan non RTH seperti SPBU atau digunakan secara illegal untuk kegiatan kaki lima. Kegiatan illegal ini umumnya dilakukan oleh masyarakat tanpa izin resmi dari Pemerintah Provinsi DKI Jakarta

e. Pemerintah juga dapat melakukan Perelokasian permukiman illegal, walaupun secara aturan Pemerintah Provinsi DKI Jakarta mempunyai hak untuk memanfaatkan asset yang dimilikinya dan juga peruntukannya memang untuk RTH 


\section{Data Peralihan RTH di DKI Jakarta}

Berdasarkan penelitian dan penghimpunan data yang dilakukan didapatkan data wilayah RTH yang telah beralih fungsi sebagaimana dari tahun 2010 hingga mei 2011 tersaji pada Tabel 4.5. berikut ini:

Tabel 8. Data Peralihan RTH di DKI Jakarta

\begin{tabular}{|c|c|c|c|}
\hline Wilayah & $\begin{array}{c}\text { Taman//alur Hijau } \\
\text { m }\end{array}$ & $\begin{array}{l}\text { Alih Fumgi } \\
\mathrm{m}\end{array}$ & Jumlah Unut \\
\hline Jkatta Selatat1 & $4.134 .452,44$ & 13880,50 & 44 buah \\
\hline Jakata I Itara & $814.006,75$ & 77000,71 & 48 buah \\
\hline Jakatta Fusat & 3765877,76 & $63.601,96$ & 60 buah \\
\hline Jakatta Barat & 895.352, (II) & $46.301,80$ & 79 buah \\
\hline Jkatta Timus & $10988.958,000$ & 96946,000 & 43 buah \\
\hline Jumlah & $1.496 .742,34$ & 207810,05 & 282 buah \\
\hline
\end{tabular}

Sumber: Dinas Tata Kota DKI Jakarta

\section{Pembahasan Hasil Penelitian}

Berdasarkan dari hasil penelitian dapat dilihat bahwa Ruang Terbuka Hijau pada wilayah DKI Jakarta hingga Juni 2011 hanya sekitar 9,12\%. Hal tersebut tentu saja tidak sesuai dengan target DKI jakarta itu sendiri yaitu 13,84\%, apalagi dengan RUTR yaitu $30 \%$.

Dengan jumlah kenyataan RTH yang ada di wilayah DKI jakarta sebesar 9,12\%. Hal tersebut juga menggambarkan bahwa lahan yang ada masih diprioritaskan menjadi lahan perindustrian, perkantoran, maupun pemukiman. Lahan yang ada lebih dinilai dari segi ekonomis penggunaan lahan tersebut seperti pembangunan mall, tempat rekreasi, perkantoran dan lain sebagainya. Hal ini dikarenakan tuntutan pertumbuhaan penduduk yang cukup pesat, sehingga kebutuhan akan lahan tempat tinggal semakin mendesak, sehingga meskipun daya dukung kota DKI Jakarta semakin hari semakin menurun yang mengakibatkan banyak bencana alam yang telah terjadi di wilayah DKI Jakarta ini, contohnya saja banjir yang selalu terjadi setiap kali hujan turun akibat kurangnya ruang terbuka hijau sebagai wilayah resapan air hujan, namun RTH masih belum diutamakan pembuatannya.

Berdasarkan pengamatan di lapangan juga banyak ditemukan RTH tidak dalam kondisi yang baik akibat kurangnya perawatan, selain itu juga banyak RTH yang tidak dimanfaatkan sebagaimana mestinya, bahkan beralih fungsi akibat kurangnya pengawasan dan ketegasan legalitas bagi setiap yang melanggar. 
RTH terluas terhadap luas kotanya terdapat pada daerah Jakarta Pusat yakni $17,20 \%$. Namun demikian, banyak RTH di kawasan Jakarta Pusat ada dalam kondisi memprihatinkan, dimana RTH yang ada tanpa pengawasan dan perawatan rutin. Sedangkan RTH pada kualitas terbaik terdapat pada kawasan Jakarta Selatan, meskipun seleksi tanaman pada RTH di kawasan tersebut belum dilakukan secara optimal.

Pada dasarnya pemerintah memiliki pengetahuan yang cukup mengenai RTH terutama pemerintah kota DKI Jakarta itu sendiri. Hal tersebut terGambar pada RUTR dan target yang mereka tetapkan sendiri. Berbagai peluang juga telah coba pemerintah manfaatkan untuk mengembangkan RTH, namun banyaknya benturan kendala seperti yang telah Saya uraikan menyebabkan jumlah RTH belum sesuai dengan target yang diharapkan.

\section{KESIMPULAN}

1. Ruang Terbuka Hijau yang dimiliki oleh DKI Jakarta hanya sebesar $9,12 \%$ yakni sekitar $59,25 \mathrm{~km}^{2}$ yang tersebar pada seluruh wilayah DKI Jakarta dengan besaran di wilayah Jakarta Utara sebesar 4,74\%, Jakarta Selatan 9,86\%, Jakarta Pusat 17,20\%, Jakarta timur 13,05\% dan Jakarta Barat 4,24\%, dengan demikian jumlah RTH di DKI Jakarta masih jauh dari target yang diinginkan yakni $13,84 \%$, apalagi RUTR yakni $30 \%$ yang berdampak pada penurunan daya dukung lingkungan DKI Jakarta sehingga menyebabkan banyak terjadinya bencana alam.

2. Setiap wilayah Administratif di DKI Jakarta memiliki bentuk ruang terbuka hijau dengan luas yang berbeda- beda pada setiap wilayah administratifnya yang diakibatkan beberapa faktor yang didasarkan pada dasar pengembangan wilayah DKI Jakarta pada rencana tata ruang wilayah DKI Jakarta.

3. RTH pada kawasan Jakarta Pusat merupakan RTH terluas jika dibandingkan dengan luasan wilayahnya, namun kurangnya pengawasan dan perawatan yang rutin menyebabkan RTH pada kawasan ini banyak dalam kondisi yang memprihatinkan.

4. RTH pada kawasan Jakarta Selatan merupakan RTH dengan kualitas terbaik dari segi perawatan, pengawasan dan tata letak, meskipun belum terdapat seleksi tanaman yang optimal. 


\section{DAFTAR PUSTAKA}

Anastasie, Ana. 1978. Evaluasi. Jakarta: Press Comunication.

Anonimuos, 1990. Kumpulan per-Undang-undangan (Lingkungan Hidup dan, Kon-servasi

Sumberdaya Alam).

Arbie. 2009. Kualitas dalam Kehidupan. Creative Instict. [terhubung berkala] http://

www.google.com. [27 Juli 2011].

Arikunto, Suharsimi. 2001. Dasar- dasar Evaluasi Pendidikan. Jakarta: Bumi Aksara.

Curtis et al. 1998. Evaluasi dan Tatanan Nilai Kehidupan. [terhubung berkala] http://

www.google.com. [5 Juni 2011]

Depdagri. 1988. Instruksi Menteri Dalam Negeri No.14 Tahun 1988 tentang Penataan RTH di Wilayah Perkotaan.

Dinas Tata Ruang DKI Jakarta. 2011. Pedoman Penyediaan dan Pemanfaatan Ruang Terbuka Hijau di Kawasan Perkotaan. Jakarta: Departemen Pekerjaan Umum.

Dinas Tata Ruang DKI Jakarta. 2011. Ruang Terbuka Hijau. Jakarta: Dinas Tata Ruang DKI Jakarta.

Echols, Shadily. 1983. Evaluasi. [terhubung berkala] http:// www.google.com. [21 Juni 2011].

Keanekaragaman Hayati. Publikasi GEO-07/2001. Jurusan Geografi FMIPA, Universitas Indonesia.

Markus. 2007. Kuantitas dan Kualitas. Masjemmy Communication. [terhubung berkala] http:// www.google.com. [27 Juli 2011].

Masbied. 2009. Kuantitas atau Kualitas. Fan Fiction. [terhubung berkala] http:// www.google.com [27 Juli 2011].

Nirwono Joga. 2010. Ruang Terbuka Hijau Berfungsi Sebagai Spon. Redaksi Biruvoice Nuansa Biru Arsitektur Lanskap. [terhubung berkala] http:// www.nuansabiru.com. [2 Februari 2011].

Nugroho, Artha. 2002. Kualitas Jiwa. Redaksi Dakwah Kampus. [terhubung berkala] http:// www.dakwahkampus.com. [27 Juli 2011].

Purnomohadi, Ning (Saya Utama), 2006. Ruang Terbuka Hijau Sebagai Unsur Utama Tata

Ruang Kota. Penerbit: Direktorat Jenderal Penataan Ruang, Departemen Pekerjaan Umum

RI. ISBN 979-15540-0-5.

Rooden. 1983. Groove and Gresswell. Jakarta: UI Press.

Sinulingga. 2002. Tata Ruang Kota. terhubung berkala] http:// www.google.com. [7 Juli 2011]. 
Soemarwoto. 2001. Daya Dukung Lingkungan. [terhubung berkala] http:// www.google.com. [7 Juli 2011].

Stufflebeam. 1979. Process of Evaluastion. [terhubung berkala] http:// www.google.com. [7 Juli 2011].

Terry. 1998. Tata Ruang Wilayah. terhubung berkala] http:// www.google.com. [7 Juli 2011].

Tim Departemen ARL Faperta IPB. 2005. Ruang Terbuka Hijau (Rth) Wilayah Perkotaan. Lab.

Perencanaan Lanskap Departemen Arsitektur Lanskap Fakultas Pertanian - IPB

Undang-undang Nomor 26 Tahun 2007 Tentang Penataan Ruang

Waryono. Tarsoen, 1990. Fungsi dan Peran Jasa Biologis Pepohonan Terhadap Lingkungan

Fisik Kritis Perkotaan. Publikasi HK-02/1990. Pelaksanaan Program Pembangunan Hutan Kota Universitas Indonesia.

Wibawa B. Etal. 2004. Pedoman Sayaan Skripsi, Pelaksanaan Ujian Skripsi, Karya Inovatif

Produktif Komprehensif dan Tugas Akhir. Jakarta: Fakultas Teknik Universitas Negeri Jakarta.

Worthern. 1979. Stufflebeam. Jakarta: Balai Pustaka.

Worthen, Sanders. 1979. Evaluasi Diri. [terhubung berkala] http:// www.google.com. [17-Mei2011. 